\title{
"The Soldier didn't Run Away, He Went Looking for Strength": Exploring Migration Imaginaries through Artistic Careers in Rap in Senegal
}

"Le soldat n'a pas fui, il est parti chercher de la force ": explorer les imaginaires migratoires à l'aune des carrières artistiques dans le rap au Sénégal «El soldado no escapo, se fue a buscar fuerza»: explorar los imaginarios migratorios a través de las carreras artísticas en el rap en Senegal

\section{Cécile Navarro}

\section{OpenEdition}

Electronic version

URL: https://journals.openedition.org/remi/13166

DOI: $10.4000 /$ remi. 13166

ISSN: $1777-5418$

This article is a translation of:

"Le soldat n'a pas fui, il est parti chercher de la force" : explorer les imaginaires migratoires à l'aune des carrières artistiques dans le rap au Sénégal - URL : https://journals.openedition.org/remi/12858 [fr]

\section{Publisher}

Université de Poitiers

\section{Printed version}

Date of publication: 1 October 2019

ISBN: 979-10-90426-64-1

ISSN: 0765-0752

\section{Electronic reference}

Cécile Navarro, "'The Soldier didn't Run Away, He Went Looking for Strength": Exploring Migration Imaginaries through Artistic Careers in Rap in Senegal", Revue européenne des migrations internationales [Online], vol. $35-n^{\circ} 1$ et 2 | 2019, Online since 01 March 2020, connection on 14 April 2022. URL: http://journals.openedition.org/remi/13166 ; DOI: https://doi.org/10.4000/remi.13166 


\section{“The Soldier didn't Run Away, He Went Looking for Strength": Exploring Migration Imaginaries through Artistic Careers in Rap in Senegal}

"Le soldat n'a pas fui, il est parti chercher de la force ": explorer les imaginaires migratoires à l'aune des carrières artistiques dans le rap au Sénégal

«El soldado no escapo, se fue a buscar fuerza»: explorar los imaginarios migratorios a través de las carreras artísticas en el rap en Senegal

\section{Cécile Navarro}

\section{AUTHOR'S NOTE}

The quotation in the title of the article is a translation of the original Wolof version "Jambaar dawul dolé ladoon wuti" (Daara J Family, 2016).

Thank you to El Hadj Diouf for the translations from wolof to French.

Still mainly unexplored (Martiniello, 2015), the study of artistic expressions in migration has made it possible to assert the important role of art in the daily lives of migrants, still mostly perceived as "workers". Martiniello et al. (2009) devote an issue of the European Journal of International Migration to theatrical, musical, poetic, literary and visual art forms that are the work of artists or artistic milieux on the move. In addition, the way artists are viewed, as highly mobile actors without being part of a socioeconomic elite, has shed new light on the analysis of transnational phenomena, as in the special issue edited by Kiwan and Meinhof published in the journal Music and Arts in Action. Musical creations used as a way of expressing the experiences of their authors 
and performers, also inform us about the production of a "migratory imaginary" that give voice to migrants themselves (Canut and Sow, 2014).

This article attempts to combine these different approaches to art in a situation of migration and mobility by engaging in a dialogue between practices, perceptions and imaginary representations of the movement (Ortar et al., 2018), based on data from an ethnographic field labelled as "tout-terrain" involved in rap music production in Senegal (artists, producers, cultural actors). Inspired by the "mobility turn" (Sheller and Urry, 2006), I considered in my doctoral research (Navarro, 2019) ${ }^{2}$ the mobility regimes (Glick Schiller and Salazar, 2013) at work in the construction of artistic careers: if mobility can give rise to new modes of recognition and success, its impossibility can also produce exclusion, marginalisation and social inequality. By artistic career, I mean - following Becker (1985) - a career that is a process of changing status and position, which evolves over time and tends towards success. It must be noted, with regard to artistic careers, that the mobility of the artist is often significant in terms of achieving a change in position and status (Le Menestrel, 2012) as well as (sometimes imaginary) success.

In this article, I seek to show more precisely how these mobility regimes appear in the light of migratory imaginary spread by songs that are the work of performers who have, themselves, experienced mobility. To do this, we will consider the migratory imaginary of certain Senegalese rap songs, not only through their lyrics and various artistic supports (notably video clips), but also with reference to what they reveal about the way in which their performers present their artistic careers as a way of reaching success through mobility. Artistic careers are reconstructed through interviews with artists and secondary sources (artist's website, press articles). Before undertaking this analysis, based on the examples of two Senegalese rap groups, Daara J Family and Wagëblë, it will be necessary to consider how rap is a particularly relevant example to apply this perspective.

\section{Rap, a faithful representation of the migrant word?}

At the end of September 2018, the Mouvement de la jeunesse de la Suisse romande (MJSR) broadcast on YouTube a music video entitled "Je viens de loin", which had been produced during a "hip-hop camp" designed to "produce, create and promote urban art and music with an artistic and social objective" ${ }^{3}$. Fifteen unaccompanied minors from various countries expressed themselves on their trajectories of migration. The choice of rap music to reflect migratory experiences is not new, nor is it without problematic elements. Beyond its easy access to non-professional musicians (Traïni, 2008), why should rap be a particularly relevant musical genre to reflect on migration experiences?

In the United States, the birthplace of rap, rap music has long established itself as an African-American mode of expression, last heir of the musical practices of African slave populations. It is therefore generally seen as more able to describe the living conditions of populations kept away from the American dream, coming from neighbourhoods afflicted by poverty, violence and discrimination (Rose, 1994). In France, the secondlargest market for the production and consumption of rap, rap music was immediately labelled as a "cultural phenomenon specific to large peripheral housing projects" (Milliot, 2006: 180). This association of rap in France with poor "suburbs" (Hammou, 
2016), and therefore with "immigration", by positioning rappers as representatives of "suburban youth" of immigrant origin and their words as a direct expression of the experience of these neighbourhoods, has established rap as a visible symbol of the problems associated with the peripheral housing projects, areas that "symbolise the concentration of exclusion phenomena and crystallise fears in the face of insecurity" (Avenel, $2009: 36$ ). On the other hand, the connection of the rappers themselves to certain territories (Forman, 2000), to migratory experiences - such as the "rap $d u$ fils d'immigré" (rap of immigrant children) identified by Clément (2015) - or to criminal experiences - which appears for example in the recurrent use of the term thug (Jeffries, 2011)-confirm these categories. By adopting and appropriating pejorative descriptions, rap artists paradoxically contribute to reinforcing these prejudices and reproducing the stereotypes that burden this artistic practice as well as the territories of which they claim to be the "representatives" (Guillard, 2012). As summarised by Bazin (2001), rap is irremediably associated with the "ghetto" and immigration.

In African contexts, on the other hand, rap is mainly perceived as the mode of expression of a particular generation (Diouf, 2002). The study of rap in an African context thus shifts the emphasis to another social category, young men who are more likely to undertake the migratory "adventure". Research that has focused on rap music in this context therefore raises the question of the role of music in the diffusion of representations of migration. In Souiah (2011), mezoued, Tunisian rap and stadium songs are chosen precisely because these particular musical genres broadcast representations of migration to the populations that migrate the most: young urban and marginalised men. In Salzbrunn et al. (2015), the popular music of Tunisian harragas, including rap, is explored as "a revealer of the migratory imagination and deep social dynamics" and is shown to be articulated around four themes: migratory desires, the dangers of the crossing, the suffering of the exile and his family, and the acceptance of the divine will.

7 In Senegal, following the increase in the number of boat departures to the Canary Islands in 2006-2007, widely referenced through the Wolof motto Barça walla Barsax ("Barcelona or die") (Willems, 2008), expressing the determination of migrants to get to Europe via Spain even at the risk of their lives, many Senegalese rap artists issued songs aimed at dissuading such "illegal ${ }^{4}$ migration" (Moulard, 2014; Rofheart, 2010). So what is the explanation for such predominantly negative representations of migration within a musical genre whose audience is itself significantly involved in undocumented migration and which rappers would be expected to "represent"?

The apparent paradox can be resolved by taking into account the conventions specific to this artistic practice, particularly as regards the status enjoyed by rappers' words in Senegal. The rapper's ability to "represent", i. e. to make explicit his links with a particular territory, is in fact what gives him the legitimacy to speak on behalf of that territory and the populations that inhabit it. Moulard-Kouka (2009) noted the appearance of new territorial boundaries in Senegalese rap as a result of the emergence of a new generation of artists claiming to belong territorially to the Dakar "banlieue" as opposed to the residential neighbourhoods in the city centre from which the pioneering groups of Senegalese rap originated. Belonging to the banlieue allowed them, they claimed, to talk about the problems that affected the Senegalese population and that their music, described as "hardcore" (i.e. uncompromising) had a duty to express. The way in which the rap performer claims to be the "representative" of a 
group is therefore subject to modes of artistic consecration based on the values of authenticity, credibility and legitimacy.

Moulard (2014), on the other hand, points out that, while rap songs on migration have tended to focus on the difficult living conditions of undocumented migrants or the danger of boat crossings, their performers have overall very different experiences of migration. Senegalese rap artist Keyti, author of the song "Eldorado", which deals with the experience of a Senegalese migrant in Europe, highlighted this gap between the experiences narrated in the songs and the performers' own experiences:

"In fact, when I was writing this text, I had never even been to France, but then, that's the power of the rap text. To really be able to imagine things, to create realities." (Interview, Dakar, 2014)

10 He explained that he was inspired by a conversation on the phone with a cousin living in France. The rapper can therefore appropriate the migratory experience from the stories of others. For Hammou (2005), the veracity of the rap story is thus more that of an "artistic work of veridiction": it plays on a truth artistically rather than reproducing that truth. In other words, rap can tell a story as long as the fiction seems true, an artistic process in which verbal violence is embedded as the only way to convey a truth that no one wants to hear. In Keyti's song, this "artistic work of veridiction" is achieved by staging a migrant voice that dares to tell the "truth" about the living conditions experienced by migrants in host countries, unlike the "real" migrants who maintain the illusions about life in Europe:

"In Senegal it's hard, but here it's not as easy as they make us believe

To find out, you have to come and see our living conditions for yourself

Because you can't imagine it

Because what they show you on television

is nothing compared to what they don't show you, they almost hide the truth from you

But guys when they come on vacation sell dreams

And, as you said, from beginning to end they pretend to be happy

Then, how to convince people that in Europe it's as difficult as everywhere else?" (Keyti,

2003, from Keyti's own translation from Wolof to French)

The Senegalese historian Benga (2002: 302) summarises this position as follows:

"In the eyes of rap artists [in Senegal], speaking out is the work of an elite, those who have the power to speak and the ability to do so. That's why rap artists, when they address young people, also speak for them."

The way these rappers represent "young people" is thus to "speak" on their behalf, rather than portraying the same behaviour. While presenting themselves as "young", rappers nevertheless act as "elder brothers", advising their listeners on how to behave. Similarly, while matching the profile of potential migrants, rappers use their means of expression to highlight the risk taken by migrants during their "clandestine" journeys.

13 Consequently, their rap songs should not only be considered as the expression of a preexisting migratory imaginary but also the location for a discourse pursued by artists who promote their positions in accordance with an artistic practice governed by conventions (Becker, 2008). This is particularly true regarding the ambivalent role of mobility in the careers of Senegalese rap artists. 


\section{Capturing Senegalese rap through the prism of mobility}

14 At the time of the celebration of the 30th anniversary of "rap galsen" (the name given by its protagonists to Senegalese rap), a date decreed by an organisation for the promotion of urban cultures, Africulturban, many rappers have developed their artistic careers through mobility. Africulturban's president, Matador, created this organisation following tours in Belgium with his previous group, Wa BMG 44. Since the organisation's creation in 2006, the reputation of its international festival, the Festa $2 \mathrm{H}$, has grown steadily thanks to the partnerships that its director, Amadou Fall $\mathrm{Ba}$, has forged around the world in his efforts to meet artists and finance their visits to Senegal. The increasing mobility of Senegalese rap artists, through tours, artistic collaborations and invitations of all kinds, has also facilitated the multiplication of home studios in Dakar thanks to the equipment financed and acquired by artists during their travels. The aspiration of many rap actors to break through abroad, noticed during my research, also corresponds to the way migration is seen by prospective migrants in Senegal as a means of self-realisation (Fouquet, 2007), a mean to escape social constraints (Mbodji, 2008), and a mean for emancipation and self-assertion (Timera, 2001).

15 These practices and imaginary of (im)mobility in Senegalese rap are part of the history of rap in Senegal and the links established through this artistic practice with the rest of the world. According to Charry (2012), the arrival of hip-hop in Senegal was due to Senegalese who migrated, particularly to France and the United States, and then returned home on holiday. Some young people, particularly among Dakar elites sensitive to trends from abroad, began imitating the bboys ${ }^{6}$ dance steps and adopting their dress codes (Herson, 2011). For Martin (2004), the United States was the primary influence on young people in African cities:

"It is because urban youth wanted to break with a rural heritage considered far too cumbersome, and with European forms too associated with colonial oppression that they chose America. Only it, in all its diversity, could give meaning to their experiences by brilliantly demonstrating their capacity for creation, and therefore for the manufacture of autonomous modernity full of the promise of an independent future."

These rap artists progressively claimed their musical expression to be authentically Senegalese, whether through the expression of territorial affiliations, the use of national languages (notably Wolof) to the detriment of French and English, or through their statements on political and social events. According to Senegalese historian Diouf (2002), the first Senegalese rappers appeared in the aftermath of the 1988 presidential elections, during which President Abdou Diouf was re-elected despite growing antagonism from a fringe of young people. Rap, he says, was the preferred mode of expression both for young people disappointed by the limitations of the Senegalese democratic model and for unoccupied young people looking for something to do during the année blanche (year when educational establishments were closed) following the elections. In the mid-1990s, artists (alongside sportsmen) personified the Bul Faale movement. Named after a song by the rap group Positive Black Soul, this movement translated into a "process of individualisation" of Senegalese youth and a questioning of the social values of the older generation (Havard, 2001). It seemed to bear fruit during the 2000 presidential elections, which ended in the victory of Abdou Diouf's 
opponent, Abdoulaye Wade, whose campaign was based on the theme of sopi ("change" in Wolof). By calling for the registration of new voters and then by calling on them to vote, the artists of Bul Faale emerged as key actors in the democracy of Senegal, a country whose peaceful presidential transitions appear as an exception in the region. In addition to this local recognition, groups such as Positive Black Soul, Pee Froiss and Daara J, which signed contracts with major international companies in the early 2000s, also received international recognition. However, this "golden age" did not last. The groups quickly broke their contracts and split up, leading to disillusionment with the possibility of Senegalese rap groups to enjoy success abroad. Other groups, such as Rap'adio and Wa BMG 44, known for their involvement in the 2000 elections and their outspoken criticism of the government, split up after some of their members left for other countries. Daddy Bibson, a former member of the Rap'adio and Pee Froiss groups, moved to Sweden and then to the United States. In the mid-2000s, rap artists migrated in numbers, whether in a documented fashion or otherwise, and this became one of the major causes of rap groups splitting up. This is what prompted rapper Maxi Krezy to write the song "Départ volontaire", which some interpreted as being specifically directed against Daddy Bibson, a childhood friend. In the song, Maxi Krezy tells how he and one of his friends planned to conquer Europe with their music by signing a contract with a record company, which would allow them to earn money and then get married. But the friend in question fails to return home when his Schengen visa expires. The third verse of the song is quite explicit about the fate he reserves for rappers who leave Senegal:

"For ten years we've been hoping to make money

In rap, everyone wonders when the song will break through in France Germany Spain

New York Tokyo we wait we never stopped yo

Fuck any rapper who's left voluntarily.

Travelling in the name of Hip Hop once you get to Europe you sell yourself believing that God

closes all access

Nigga, what do you think the future of Senegalese hip-hop would be if everyone did what you

did,

The young people who follow you and motivate you, who will encourage them?

In any case, the ones who stayed and I are sending you this letter

If, however, you have soiled your hands by wiping the asses of white children

Don't touch our mics anymore you're cats who wanted to play smart to become lions, we're not friends anymore

The adventure must be sincere and since you have taken another road (...), you are freed" (Maxi Krezy, 2003, from a translation from Wolof to French by El Hassan Diouf, journalist at Rapdjolof.com)

This definition of the rap artist as one who "encourages young people" and fights for the future of his country leads to a conception of migration as a cowardly act, by which the rapper gives up his role in Senegalese society and breaks with rappers who have remained in Senegal. Consequently, as pointed out by one rap artist, who now resides in Paris, the desire of artists to migrate, although very common, is rarely acknowledged:

"In Senegal, 90\% of artists who do hip-hop, who do rap, even if they don't say it, it's true that

this is what it's all about, travelling." (Interview, Paris, 2017)

Therefore, no analysis of the migratory imaginary in Senegalese rap songs can ignore the ambivalent relationship of these artists with mobility: a source of artistic recognition, the artist's mobility is presented as desirable as long as it does not lead to a definitive departure, which would then call into question the reputation of the artist 
as bounded to the future of his country. The representations of migration as they appear in songs must therefore be seen in relation to the artistic career and mobility experiences of their performers.

The relevance of this perspective is revealed by a comparative analysis of two rap groups: an internationally recognised group that has never left Senegal (Daara J Family) and a group whose members have gone abroad, but which continues to make music aimed, at least in part, at the Senegalese public (Wagëblë).

\section{Daara J Family, "Senegal is your shelter."}

The group is composed of two high school friends, Ndongo D and Faada Freddy. The latter's Uncle, who lived in France, frequently brought back music and cassettes in his suitcases. It is by this means that the two friends discovered hip-hop through the recordings of DJ Sidney's shows, broadcast in 1984 on French television channel TF1. They met the third member of the group, Alaji-man, during a rap evening organised at Metropolis $^{7}$ in 1993 and formed the group Daara J in 1994. A year later, the group published its first eponymous cassette, which achieved great success in Senegal, with 15,000 copies sold. Alongside groups such as Jant bi and Sunu Flavor, Daara J concentrated mainly on love themes in its music. However, the band's originality lies in the musical expression of its members' religious beliefs, which allowed them to win over a wide audience. The term Daara ji is notably used in Senegal to designate the Koranic school.

21 It was in France that the group was "discovered" by an English producer, Carlton Cigler, who remixed the songs on their cassette for their first international album, published under the French label Déclic Communication in 1997, which also released their next album, Xalima, a year later. That album allowed them to tour Europe (France, Belgium, Spain and Germany) in the year 2000.

Wishing to gain international recognition beyond the French-speaking market, the members of the group broke their contract with the label to sign on with the English subsidiary of the major company BMG Entertainment (which merged with Sony BMG to become Sony Music in 2005). In 2003, the group released its third international album Boomerang, which included collaborations with several internationally renowned artists, including the Malian singer Rokia Traoré and the French rapper Diziz La Peste. The group embarked on a French tour during which it opened for Rita Missouko at Le Grand Rex in Paris. After years of concerts abroad, as well as winning the prestigious BBC World Music Awards for Best African Artist in 2004, the band's international career eventually failed to take off. In 2007, Alaji-Man left the group and the two remaining members renamed themselves Daara J Family.

In 2010, the group released its new album School of life under the British label Wrasse Records, specialised in world music. According to Ndongo D, by classifying them as "world music", the label prevented them from being taken seriously as rappers ${ }^{8}$ and this led them to break their contract again.

In 2013, Faada Freddy began his solo collaboration with French label ThinkZik, recently created by the Franco-Senegalese Malick Ndiaye, nephew of the Senegalese musician and composer Wasis Diop. Faada Freddy produced a new project, Untitled, whose concept was to have all instrumental parts interpreted by human voices and body 
percussion. A year later, when I was beginning my research, I happened to meet Ndongo D in Senegal, after having tried in vain on several occasions to contact the members of the group (who were very frequently abroad). He invited me to meet him in the studio of their independent label, Bois sakré, where I found him working on the songs for their next album Foundations, to be released in 2016. During this session, he made me listen to the song "Senegal", which he presented to me as intended for the Senegalese diaspora. I pointed out to him that the group had expressed itself on many occasions on the subject of migration in its songs. Ndongo D replied that this was a subject that the group knew about from personal experience. In the song "Exodus" from the Boomerang album, dedicated to "all the illegal immigrants, all the bana bana (name given to Senegalese Street vendors) who are looking for Eldorado in Americana", the artists echoed representations of migratory destinations as an "Eldorado" or "Promised Land" to which migrants went in the hope of a better life and from which they promised to return with "pockets full of gold".

On the other hand, the primary intention of the song "Senegal" is to encourage migrants to return to Senegal, both by making them feel homesick for the country and by evoking a happy outcome to the migration experience. The title can also be understood as a demonstration of the artists' love for their country ("I love this country that has seen me grow") or as tourist promotion aimed at a foreign audience?

In "Senegal", the two members of Daara J Family express feelings of nostalgia when "far from home" and loved ones. The country is associated with a house, a "shelter" to which the migrant is called upon to return, while migration is presented as uprooting. The return is experienced as a fulfilment to which the migrant naturally aspires. Life abroad is therefore viewed as a parenthesis with only one goal, that of "preparing the way for the return". The suffering experienced abroad is thus made acceptable by the promise of returning home as a winner (Banégas and Warnier, 2001).

In "Senegal", Ndongo D addresses the migrant in Wolof:

"You're far from home, dreams that we welcome you

one day you'll come home, prepare the way back

know that you are close to your goal, family, everyone is waiting for you,

you were gone but you came back, Senegal is your shelter" (Daara J Family, 2016, from a

translation from Wolof into French by El Hassan Diouf, journalist at Rapdjolof.com)

Faada Freddy replies: "Here I am again at home, where I feel like a king."

Viewed chronologically in the perspective of the stages of Daara J's and then Daara J Family's artistic careers, the two songs acquire a new meaning. In the song "Exodus", issued in 2003 when the band was under contract to a record company that made them hope for international fame, the group members believed in their success through migration, like the "illegal immigrants" to whom the song was dedicated. By contrast, in the song "Senegal", issued as part of an album that presented itself as a return to the group's Senegalese roots or "foundations", and which was produced independently, the lyrics highlight the theme of return from migration and hence of Daara J Family's return to Senegal. The song "Senegal" is therefore symbolic of the careers of the members of the group, who, after years of working internationally, are keen to express their attachment to a country of origin that they have never really left. As Ndongo D told me in 2014, it was important for members to return regularly to Senegal, usually every six months. This resonance of the migratory imaginary with the staging of artistic identity is particularly highlighted when Faada Freddy sings that "the soldier 
did not flee, but that he went to seek strength". Just as the soldier should not be accused of desertion, since he fled only to return stronger, the group itself cannot be blamed for abandoning their country, since they did so for the same reason.

Early 2018, Faada Freddy returned to Senegal after a series of concerts in Europe to promote his solo album and gave two concerts, presented in the national press as a triumphant conclusion to the artist's international tour. Interviewed by Radio France International, Faada Freddy commented on his return to Senegal: "It's like being reborn. Every time I come here, I recharge my batteries. Every time I come back to Senegal, I feel like it's the first time" (Thibault, 2018). In the career of Daara J Family and later in Faada Freddy's solo career, the mythology of the return home as an achievement is thus regularly reactivated to the benefit of the group's prestige. Through migration, "one increases one's reputation by surrounding oneself with the prestige attached to Elsewhere and its accessories and thus becoming the incarnation of Illusion" (Fouquet, 2007): "leaving to grow, coming back to build", as the group proclaims at the end of "Senegal".

\section{Wagëblë, a migration with no return?}

31 Wagëblë is a group composed by rappers Waterflow and Eyewitness. The two members met in high school in 1994 and formed a first group with two other rappers who then went abroad. Wagëblë, which means "of the ghetto" ("wa" meaning "of the group of" and "gëblë" for "ghetto") is also the acronym for Wax Aduna Geddu Ettu Baatin Lemu Ëlek, which means, in Wolof, a communal meeting place where people discuss the issues that affect their lives. As their name suggests, the group is part of the "hardcore" movement that uses rap to make the "voice of the voiceless"10 heard.

The members of the group, originally from Thiaroye, present it as one of the first groups from the "banlieue" and emphasise on the difficulty of finding a place for themselves within a musical scene then dominated by groups from Dakar city centre. According to Eyewitness, met in Lausanne, where he now lives, it was during auditions that the group was spotted by Norwegian producer Tom Roger of the Two Thou Entertainment label in the early 2000s, even though the studio owner had expressed some reservations about letting it audition. This version of the group's early days, which contrasts with other versions, is designed to highlight its difficulties in getting recognised, as if to justify how the rapper has distanced himself from other rap artists in Senegal, about whom he was critical throughout our meeting.

Be that as it may, the group's first album, recorded in Dakar with Tom Roger, was released in 2003 and was a huge success. Their second album, Senegal, likewise recorded by Two Thou Entertainment, was recorded in Norway and released in 2005. The group then went on an international tour (in the United States, Norway, Switzerland, Sweden, France, Gambia and Guinea). Between 2002 and 2005, while their two albums were being recorded and they were touring abroad, the group travelled a lot, returning to Senegal every six months. According to Waterflow, it was in 2005 that the members of the group left Senegal to settle more permanently abroad. Whereas Eyewitness settled very quickly in Switzerland after only a short stay in Norway (when I met him in 2014 he told me he had been in Switzerland for ten years), Waterflow lived first for a few months in Switzerland with Eyewitness, then in Norway with frequent returns to Senegal, before eventually settling in the United States a few years later, to gather with 
his American wife and their baby. He became a manager of a Belgian restaurant to provide for his family. Despite the geographical distance and their professional activities, the group released a third album, Message of Hope, in 2011 on their independent label, Nubian Spirit. Waterflow, met in the United States in 2015, explained this break with the Norwegian label to me as a way of acquiring a new autonomy. From that moment on, the group took charge of all aspects of their artistic activity: not just production, recording and mixing, but also album cover design, concert management, logistics, video production and the development of a clothing brand. According to the rapper, the title of the album Message of Hope symbolises the group's evolution as the embodiment of a message of hope: that of having succeeded by their own efforts. This message also refers to the success of their own lives, starting from "nothing, from the poorest places" and using what they had at their disposal to "get where we are now" (Interview, Washington, D.C., 2015).

This success is illustrated in the song "African Dream" from the Message of Hope album. This "dream" is not presented in an exclusively positive light, since the two rappers share the sacrifices they had to make and highlight the difficulties of continuing their artistic career as emigrants. The music video explicitly shows the temptation faced by the migrant in order to earn money. It begins with a sequence, without music, during which two individuals are filmed talking at the bottom of a building, while rolling joints. The first, probably a recruiter for drug dealing, asks the second, one of his new dealers if he did good business last night. The dealer replies that he made a lot of money and that he loves this job. One of the members of Wagëblë passes a few metres in front of them to get to his apartment. The two men talk about him:

The recruiter:"When you see that nigga over there man, going back and forth, back and forth, I don't know what he do man. Do he do music man? Or something like that?"

The dealer:"Man, music man, they don't have any money, man"

The recruiter:"Yeah?"

The dealer:"Leave it leave it (tchiip). Music?"

The recruiter:"That's right man we got to do our own, we here to make some dough. We don't do no music."

This conversation gives way to another sequence that shows Waterflow in his bathroom, looking at himself in the mirror. The next sequence shows Eyewitness in front of his computer. He is on the phone with a member of his family and explains that he does not know when he will return to Senegal. He hangs up, looks at photographs from his last stay in Senegal, and starts writing the song, "African Dream".

In their respective verses, the two rappers tell of their desire to return home, but also of their determination not to give up "the mission". The chorus, sung by the renowned Senegalese musician and singer Ismaël Lo, proclaims that "Africa is waiting for them". The group is filmed in a music studio, then images show them in Senegal. The end of the video returns to the conversation from the beginning, where the two men are still discussing Waterflow, saying that he has no money and will be deported. The last image of the clip shows the group members with their backs to the camera, looking towards the horizon as if to signal the promise of a better tomorrow.

The song fulfils several objectives for the group: foremost, it meets the expectations of their audience, explaining why the group has not yet returned to Senegal and telling them that, despite the difficulties, the group continues to exist. The release of the album was supposed to be accompanied by a tour in Senegal, after the group's participation in the World Festival of Negro Arts ${ }^{11}$ (Festman). According to an interview 
conducted by the group members on that occasion (Senerap, 2011), the group preferred to postpone the tour, which did not take place in the end, due to organisational problems. Their performance at the Festman also revealed their loss of popularity with a younger rap audience that did not know the group before their departure abroad. For the group, the return was a failure, which reinforced the distance taken from their country.

When asked about his relationship with the Senegalese audience during our meeting in the United States in 2015, Waterflow told me that he did not seek to reach a specific audience or to correspond to the characteristics of the music defined as "Senegalese rap", an approach described by him as overly restrictive:

"If you're Senegalese, you think you're doing Senegalese rap, a rap that's just focused on Senegalese culture, that only talks about the problems of Senegalese people. So there you go, you close up. While rap, in its essence, is a universal culture."12

However, Waterflow still defines himself as a Senegalese rapper: Senegal is his origin, “it's in my DNA, but it doesn't determine where I'm going to live all my life" ${ }^{13}$, he told me.

By saying that his origin does not determine where he ought to live, he claims the right for each individual not to be constrained by circumstances, but to choose his own destiny or, in other words, "to develop himself" - terms that he uses to justify his desire to leave Senegal, identifying with an imaginary of migration as a way to extricate oneself from the social values that prevent the individual from succeeding (Mbodji, 2008). According to Waterflow, the social values concerned are those imposed on artists by the expectations of the Senegalese audience. This migratory imaginary also blends into the American myth of the self-made man. However, as the successful rap artist must remain "real" (Sköld, 2007), Waterflow says that, despite migrating, he has remained the same and claims still to act as "the voice of the voiceless".

It was towards the end of 2016 that the band finally returned to Senegal for the Galsen hip-hop Awards ceremony, ahead of the release of their new album, which was to be called Witness the Flow (a pun on their stage names). On stage, the band performed hits from their first two albums to try to reconnect with the Senegalese audience. Wagëblë's next album, which has not yet been released, includes two singles, "Jawale" and "Jambaar", which were released in August 2016 and October 2017 respectively. In the "Jawale" music video, the group members film themselves on the Hollywood walk of fame, the sidewalk adorned with 2,600 stars representing world-famous celebrities. In the "Jambaar" music video, by contrast, they show themselves facing the sea, from the beaches of Ngor, at the north-western end of the city of Dakar, and on the esplanade of the African Renaissance Monument ${ }^{14}$. This artistic production thus reflects Wagëblë's oscillation between Senegal and the United States, between the image of the migrant who has succeeded abroad and the return home.

As with Daara J Family, the chorus of the title "Jambaar" proclaims that "the warrior has gone to seek strength". According to Wagëblë, migration can also be explained in terms of the search for better prospects elsewhere. However, unlike Daara J Family's, Wagëblë's migratory experience has not yet concluded on a definitive return to Senegal, as reflected in the verses of the two rappers. Waterflow in particular reminds us that the "real" soldier "works hard" and "takes off", thus demonstrating his determination to succeed and overcome all difficulties, despite criticism:

"To succeed or die, fuck my enemies.

Work hard and take care of my business 
Go around the world I brag if I want to I'm rude and own it

You don't understand, there's only God.

He's the one who gives me courage

I have nothing to fear" (Wagëblë, 2017, from a translation from Wolof to French by El

Hassan Diouf, journalist at Rapdjolof.com)

\section{The figure of the "jambaar", between migratory imaginary and artistic positioning} unscrupulous individuals who seek rapid success at all costs. For example, in Bredeloup (2008: 289), "adventurers" are diamond traffickers for whom "self-realisation takes precedence over economic projects" in accordance with new models of success corresponding to a "new moral economics imbued with the imaginary of the State valuing and legitimising get-rich-quick careers, schemes and scams, in other words, all the heterodox registers of individual promotion, whatever they may be" (Ibid.: 291). By contrast, Havard (2001) pointed to the emergence of a "Bul Faale ethos" in Senegal, promoted by rappers and wrestlers, as a model of success based on an ethic of effort and work. Thus, the "adventurer", the unscrupulous fortune-hunter, and the member of the Bul Faale, who thanks to his efforts manages to overcome the obstacles posed by society, are seen as two a priori contradictory figures of success.

the many Senegalese rap songs about migration, very few mention "adventure". On the other hand, a warlike vocabulary is prominent, with references to "combat" or "mission" as well as "war" and "battle". The metaphors refer to the "warrior", but also to the "military", the tirailleur and the "soldier" as well as to the "enemies", that they 
"counter", "fight", "brutalise" and "destroy". They "shout", "invade", "kill", "burn" and show "strength", "courage", "determination" and a "thirst to overcome". Finally, the warrior has "weapons", is "armoured like a tank" and delivers "blows". This warrior rhetoric is not in itself surprising. Bazin (2001) already pointed out how rap artists were inspired by war imagery and considered rap as a weapon, a metaphor often associated with the birth of rap in the United States. The Zulu Nation movement's slogan "Love, peace and having fun" illustrates how hip-hop was presented as an alternative to gang violence: rather than physical violence, gang members would compete in dance, djing and rap battles. In Senegal, the warrior metaphor is important in hardcore rap and its association with poverty. The hardcore rapper is "committed and conscious" but, by extension, also a "tough guy" or in other words, a "jambaar" (Moulard-Kouka, 2008). On the other hand, the figure of the "soldier" is mentioned in some works on the migratory imaginary. Thus, if Bredeloup (2008) emphasises on the figure of the "adventurer", perceptible through the vocabulary of resourcefulness, cunning or luck, she stresses that the adventure also has a warrior dimension, because the migrant must overcome trials thanks to his courage, recklessness, bravery and pride. In a text published in 2018, Mourre shows how the figure of the Senegalese tirailleur $^{15}$ is mobilised in the creation of the migratory imaginary, particularly through the collective memory of the "blood debt". The sacrifice of the Senegalese tirailleurs during the Second World War is avenged by migrants who come to claim payment of this debt, a theme found in many Senegalese rap songs. In the light of the careers of the artists concerned, as well as the accusation of betrayal levelled at artists who leave, by artists who remain in Senegal, as discussed above, I would nevertheless argue that the figure of the warrior can be viewed as an alternative to that of the "adventurer".

Firstly, unlike the "adventurer", who leaves "to try his luck" and "discover the world", led above all by his quest for exoticism and his desire for money, the "soldier" has a "mission": he does not flee his country, he simply goes elsewhere to "seek strength" and bring that strength back to Senegal. Secondly, unlike the "adventurer", whose success is achieved at any price, the soldier retains a sense of duty and dignity (jom in Wolof). In the "African Dream" music video, the aim of the cinematography is to showcase the efforts made by Wagëble's members not to deviate from their primary "mission", to move their music forward, when faced by the temptation of more profitable illegal activities such as drug dealing. The "war" that the rapper wages is here an internal war, against his own impulses to deviate from the "right path". This internal war may be similar to the notion of jihad as propagated by Sufi Islam, most notably by Sheikh Ahmadou Bamba, the Senegalese religious leader and founder of the Murid brotherhood (Babou 2007). According to Lamchichi (2005: 29), writing about Sufism, "the most important struggle is at the inner level, at the level of asceticism, of the major jihad (moral or spiritual) that the believer must first wage against himself, 'with the help of his heart', to expel from himself the negative impulses". Unlike the "adventurer", the "soldier" does not sacrifice his dignity in the name of success. To borrow Maxi Krezy's expression, the rapper must show that he has not gone to "wipe the asses of white children" and, therefore, that he is still worthy to take the microphone.

48 By presenting themselves as soldiers, these artists claim not to have given up their "mission" as rappers and counter suspicions of illegal activities associated with their 
migration, thus allowing them to negotiate the continuity of their membership of the Senegalese rap scene, despite migrating.

\section{Conclusion}

This article has sought to address the migratory imaginary present in Senegalese rap songs, by understanding them in the perspective of the artistic careers of their performers. Musical creation is not only about revealing imaginary about migration, and rap is not solely a faithful representation of the migrant experience. The migratory imaginary must be re-examined through the processes of musical creation, which involve a set of actors sharing a number of conventions. Consequently, each musical genre can be a forum for refreshing the meanings attached to this migratory imaginary. In Senegal, rappers have thus widely opposed "clandestine" migration, by deconstructing fantasies about Europe, and have, in a way, sought to counter an existing migratory imaginary by denouncing the idea of migration as the only means of social achievement. In the wake of this, they have been led to conceal their own intense desire to migrate and the ambivalent relations they maintain with a West that is both criticised and admired by many of them. The act of staying in Senegal is the basis for fulfilling the "mission" of a rapper to fight for the future of his country, despite the crucial role played by mobility in the careers of a growing number of artists. The exploration of this imaginary in the light of performers' careers thus illuminates processes of inclusion and exclusion within those of musical creation: for those whose migratory experience, and return home, are not justified by success, the migratory experience becomes a "source of alterisation and exclusion between supposed 'true' and supposed 'false"' (Timera $2014: 47$ ). The use of the figure of the "soldier", by presenting itself as a positive alternative to the "adventurer", then becomes a way to circumvent these processes of inclusion and exclusion by claiming a continued attachment to Senegalese rap, despite the migratory experience.

\section{BIBLIOGRAPHY}

Avenel Cyprien (2009) La construction du « problème des banlieues » entre segrégation et stigmatisation, Journal français de psychiatrie, 34, pp. 36-44.

Babou Cheikh Anta (2011) The Jihad of the Soul. Ahmadou Bamba and the founding of Mouridiyya in Senegal (1853-1913), Paris, Karthala Éditions, 366 p.

Banégas Richard and Warnier Jean-Pierre (2001) Nouvelles figures de la réussite et du pouvoir, Politique Africaine, 82, pp. 5-23.

Bazin Hughes (2001) La culture hip-hop, Paris, Desclée de Brouwer, 305 p.

Becker Howard (2008) Art Worlds, Berkeley, University of California Press, 410 p. 
Becker Howard (1985) Les carrières dans un groupe professionnel déviant : les musiciens de danse, in Howard Becker, Outsiders : Études de sociologie de la déviance, Paris, Editions Metaillée, pp. 126-144.

Benga Ndiouga Adrien (2002) Dakar and its tempos Meanings and challenges of modern urban music (c.1960-1990s), in Momar Coumba Diop Dir, Le Sénégal contemporain, Paris, Karthala, pp. 289-308.

Bredeloup Sophie (2008) L'aventurier, une figure de la migration africaine, Cahiers internationaux de sociologie, 125, pp. 281-306.

Canut Cécile and Alioune Sow (2014) Voices of Migration. Speeches, stories and artistic productions, Cahiers d'études africaines, 213-214, pp. 9-25.

Charry Eric (2012) Hip Hop Africa: New African Music in a Globalizing World, Bloomington, Indiana University Press, 404 p.

Clément Pierre-Alain (2015) La signification du politique dans le rap, Cultures \& Conflits, 97, pp. 123-141.

Daara J (2003) Exodus, in Boomerang, BMG France, CD.

Daara J Family (2016) Senegal, in Foundations, Sakré Wood, [online] consulted on 30/08/2015. URL : https://www.youtube.com/watch?v=JpvDC_s8aDg

Diouf Mamadou (2002) Les cultures urbaines entre traditions et mondialisation, in Momar Coumba Diop Dir, Le Sénégal contemporain, Paris, Karthala, pp. 261-288.

Fouquet Thomas (2007) Migratory Imaginary and Multiple Experiences of Otherness: A Present Dialectic of the Near and Far, Autrepart, 41 (1), pp. 83-98.

Forman Murray (2000) “Represent”: race, space and place in rap music, Popular Music, 19 (1), pp. 65-90.

Glick Schiller Nina and Noel B. Salazar (2013) Regimes of Mobility across the Globe, Journal of Ethnic and Migration Studies, 39 (2), pp. 183- 200.

Guillard Séverin (2012) « Representing your city » : the anchoring of urban identities in Twin Cities rap, Cybergeo: European Journal of Geography, [online] consulted on 10/08/2018. URL: https:// doi.org/10.4000/cybergeo.25357

Hammou Karim (2016) Rap et banlieue : crépuscule d'un mythe ?, Informations sociales, 190, pp. 74-82.

Hammou Karim (2005) How does the social world of rap develop its territory? Contemporary Societies, 59-60 (3), pp. 179-97.

Havard Jean-François (2005) Bul faale! Thèse de sociologie politique, Université Lille 2, 729 p.

Herson Ben (2011) A Historical Analysis of Hip-Hop's Influence in Dakar from 1984-2000, American Behavioral Scientist, 55 (1), pp. 24-35.

Jeffries Michael P. (2011) Thug Life: Race, Gender, and the Meaning of Hip-Hop, Chicago, University of Chicago Press, $274 \mathrm{p}$.

Keyti (2003) Eldorado, in Jog ak Daanu, Cassette.

Kiwan Nadia and Meinhof Ulrike Hannah (2011) Music and Migration: A Transnational Approach, Music and Arts in Action, 3 (3), pp. 3-20. 
Lamchichi Abderrahim (2005) Jihâd. A fight against which opponent?, Words. Les langues du politique, 1 (79), pp. 21-33.

Le Menestrel Sara (2012) Des vies en musique. Parcours d'artistes, mobilités, transformations, Paris, Éditions Hermann, 200 p.

Martin Denis Constant (2004) Les musiques en Afrique, révélateurs sociaux, Revue Projet, 283, [online] consulted on 05/10/2017. URL: http://www.revue-projet.com/articles/2004-11-lesmusiques-en-afrique-revelateurs-sociaux/

Martiniello Marco, Puig Nicolas and Gilles Suzanne (2009) Editorial: Creations in migration, Pathways, displacements, roots, European Journal of International Migration, 25 (2), pp. 7-11.

Maxi Krezy (2003) Voluntary departure, in Palanteeru Wallanteeru, Cassette.

Mazauric Catherine (2012) Mobilités d'Afrique en Europe : récits et figures de l'aventure, Paris, Karthala, 383 p.

Mbodji Mamadou (2008) Imaginaires et migration : le cas du Sénégal, in Momar-Coumba Diop, Le Sénégal des migrations : mobilités, identités et sociétés, Paris, Karthala, pp. 305-320.

Meyer Michaël, Adeline Perrot and Isabelle Zinn (2017) Between "off-road" ambition and impossible ubiquity: ethnographers in motion, SociologieS, [online] consulted on 04/01/2018. URL: http://journals.openedition.org/sociologies/6521

Milliot Virginie (2006) The "French Touch": hip-hop at the filter of republican universalism, Anthropology and societies, 30 (2), pp. 175-97.

Moulard Sophie (2014) Le regard entre deux rives. La migration et l'exil dans le discours des rappeurs sénégalais, Cahiers d'Études Africaines, 213/214, [online] consulted on 01/07/2014. URL : https://www.academia.edu/7500056/

Le_regard_entre_deux_rives._La_migration_et_lexil_dans_le_discours_des_rappeurs_senegalais_Cahiers_detudes_africaines_2014

Moulard-Kouka Sophie (2009) Le rap à Dakar. Mise en perspective du local et du global dans une culture populaire urbaine au Sénégal, in Yves Raibaud Éd., Comment la musique vient aux territoires, Pessac, Publications de la Maison des sciences de l'homme d'Aquitaine, pp. 153-163.

Moulard-Kouka Sophie (2008) «Senegal yewuleen! “Analyse anthropologique du rap à Dakar : liminarité, contestation et culture populaire, Thèse d'anthropologie, Université Victor Segalen-Bordeaux II, 575 p.

Mourre Martin (2018) Mémoire des tirailleurs et institutions des imaginaires migratoires au Sénégal dans les années 2000, Africa, 88 (3), [online] consulted on 12/08/2018 URL : https:// www.cambridge.org/core/journals/africa/article/african-colonial-soldiers-memories-andimagining-migration-in-senegal-in-the-twentyfirst-century/

57572DEDD31827E4DEAA5CB6A1CFDD8A\#

Navarro Cécile (2019) 'It is not rap that makes us travel, it is us who make rap galsen travel' : Practices and Imaginations of (im) mobility within a translocal music scene in Senegal, Thesis in Social Sciences, University of Lausanne, $468 \mathrm{p}$.

Ndiaye Corréard-Geneviève (Dir.) (2006) Les Mots du Patrimoine. Le Sénégal, Paris, Éditions des Archives Contemporaines-AUF, $600 \mathrm{p}$.

Ortar Nathalie, Monika Salzbrunn and Mathis Stock (2018) Migrations, circulations, mobilities. Nouveaux enjeux épistémologiques et conceptuels à l'épreuve du terrain, Aix-en-Provence, Presses Universitaires de Provence, $230 \mathrm{p}$. 
Pian Anaïk (2009) Aux nouvelles frontières de l'Europe : l'aventure incertaine des Sénégalais au Maroc, Paris, La Dispute, 237 p.

Rofheart Mahriana (2010) Don't abandon 'our boat' : shifting perceptions of emigration in contemporary Senegalese literature and song, Thèse en philosophie, Rutgers University/Graduate School, New Brunswick, $204 \mathrm{p}$.

Rose Tricia (1994) Black Noise: Rap Music and Black Culture in Contemporary America, Hanover, NH, Wesleyan University Press, 237 p.

Salzbrunn Monika, Souiah Farida and Simon Mastrangelo (2015) Les "brûleurs" de frontières dans la musique populaire tunisienne, Afrique Contemporaine, 2 (254), pp. 37-56.

Senerap (2011) Wagëblë : Exclusive Interview, Skyrock (blog), [online] consulted on 21/02/2018. URL: https://senerap.skyrock.com/3032599760-WAGEBLE-EXCLUSIVE-INTERVIEW.html

Sheller Mimi and John Urry (2006) The New Mobilities Paradigm, Environment and Planning A, Economy and Space, 38 (2), pp. 207- 226.

Sköld David (2007) Makin' It, by Keeping It Real. Street Talk, Rap Music, and the Forgotten Entrepreneurship from "the 'Hood", Group and Organization Management, 32 (1), pp. 50- 78.

Souiah Farida (2011) Musique populaire et imaginaire migratoire en Algérie, Diversité, 164, pp. 27-33.

Thibault Guillaume (2018) Faada Freddy back in Senegal, RFI Musique.fr, [online] consulted on 16/04/2018. URL: http://musique.rfi.fr/musique-africaine/20180112-faada-freddy-retour-senegal Timera Mahamet (2014) Words and evils of migration. From Anathema to Praise, Cahiers d'études africaines, 213-214, pp. 27-47.

Timera Mahamet (2001) Les migrations des jeunes Sahéliens : affirmation de soi et émancipation, Autrepart, 18, pp. 37-49.

Traïni Christophe (2008) La musique en colère, Paris, Les Presses de Sciences Po, 122 p.

Wagëblë (2017) Jambaar, Nubian Spirit, [online] consulted on 09/10/2017. URL: https:// www.youtube.com/watch?v=kfzI28pBd8g

Wagëblë (2016). Jawale, Nubian Spirit, [online] consulted on 28/08/2016. URL: https:// www.youtube.com/watch?v=LHnVLjw9ScQ

Wagëblë (2011) African Dream (Wagëblë Feat. Cheikh Lô), Message of Hope, [online] consulted on 29/11/2014. URL : https://www.youtube.com/watch?v=SLd4qm5_W_Q

Willems Roos (2008) Les 'fous de la mer' : les migrants clandestins du Sénégal aux Îles Canaries en 2006, in Momar-Coumba Diop Éd., Le Sénégal des migrations : mobilités, identités et sociétés, Karthala Éditions, pp. 277-303.

\section{NOTES}

1. By "tout-terrain", the authors of this dossier of Sociologies designate the ethnographic terrain that takes place beyond a prolonged co-presence on a single place. The ethnographer is for example more and more often led to follow a phenomenon that crosses several places. My practice of "tout-terrain"was achieved by going to different places where Senegalese rap music was created and listened to, including on the Internet, as well as by organizing a repeated copresence with the artists in different locations in Dakar and abroad, during mobility experiences. 
2. This research, conducted between 2014 and 2018, was carried out with the support of the Swiss National Science Foundation (SNSF) and under the direction of Monika Salzbrunn (ISSRUniversity of Lausanne) and the co-direction of Heidrun Friese (TU Chemnitz).

3. https://www.20min.ch/ro/musique/news/story/Ils-racontent-leur-migration-dans-un-clipde-rap-12928596

4. This is the term used in the artistic creations concerned. However, I prefer to use the term "undocumented migration": it is the absence of documents and not the illegality of the act that defines such migration.

5. This term is used to refer to the neighbourhoods on the outskirts of Dakar city as well as the three other cities in the Dakar region (Pikine, Guédiwaye, Rufisque). These densely populated areas concentrate urban development problems - uncontrolled development, lack of infrastructure, frequency of flooding - which are, in the eyes of rappers, a sign of the lack of interest shown by political decision-makers in these areas and the people who inhabit them.

6. First hip-hop dancers (Bazin, 2001).

7. Former nightclub in the centre of the capital, now converted into a restaurant.

8. Field notebook (2014) Visit to Ndongo D (Daara J Family), Grand-Yoff/Dakar, Senegal, 10/11/2014.

9. The Senegal clip was produced in collaboration with the Senegalese Agency for Tourism Promotion.

10. Senegalese rappers known as "hardcore" build their "musical commitment" as the fact of using their media, music, to make the voices of populations heard that would not, according to them, be listened to by political decision-makers and more broadly, would be unheard in the globalized system.

11. The 2010 World Festival of Negro Arts, organized under the chairmanship of Abdoulaye Wade on the theme of the African Renaissance, was the third edition of the festival, after the 1966 edition organized by Léopold Sedar Senghor in Dakar, and the 1977 edition held in Lagos (Nigeria).

12. Waterflow (Wagëblë) (2015) Interview, Washington, United States, 01/10/2015.

13. Ibid.

14. The monument is a fifty-two metre high statue of an African man hugging a woman and carrying a child on his left arm. The child points his finger across the Atlantic in the direction of far-off America, symbolizing an Africa that is reborn by standing tall and aspiring westward.

15. The Senegalese tirailleurs, a body of African soldiers recruited in the colonial troops of the French colonial empire, formed in 1857, bear this name because of the large number of Senegalese among its ranks. From 1857 to 1905, the regiment consisted of freed slaves bought by the French from their African masters. These numbers were gradually reinforced by contributions from prisoners of war and volunteers. Towards the end of the 19th century, members of the African ruling classes were integrated as non-commissioned officers. During the Second World War, the Senegalese tirailleurs were among the soldiers on the front line in the reconquest by the Allied forces of the French territory occupied by the Nazi regime.

\section{ABSTRACTS}

From the study of migration imaginaries to the study of artistic mobilities, taking into account artistic expression has considerably renewed the approach of migrations. In particular, musical 
productions have been considered as a privileged way of collecting migration imaginaries. Is music, and especially rap, only then the faithful representation of a migrant voice? By putting migration imaginaries in perspective with the lived experiences of mobility during artistic careers, developing on the examples of Senegalese rap groups Wagëblë and Daara-J Family, the article shows how artists can appeal to a particular migration imaginary, that of the "soldier" rather than that of the "adventurer" to stage their artistic career, according to the conventions specific to the musical genre to which they wish to belong.

De l'étude des imaginaires migratoires à l'étude des mobilités artistiques, la prise en compte de l'expression artistique a considérablement renouvelé l'approche des migrations. Les productions musicales ont notamment été considérées comme une manière privilégiée de recueillir les imaginaires migratoires. La musique, et notamment le rap, n'est-elle alors que la représentation fidèle d'une parole migrante? Par la mise en perspective des imaginaires migratoires avec le vécu des mobilités au cours de carrières artistiques, à partir des exemples des groupes de rap sénégalais Wagëblë et Daara-J Family, l'article montre comment des artistes peuvent faire appel à un imaginaire migratoire particulier, celui du «soldat " plutôt que celui de l'« aventurier » pour mettre en scène leurs parcours artistiques, en fonction des conventions propres au genre musical auquel ils souhaitent appartenir.

Del estudio de los imaginarios migratorios hasta el de las movilidades artísticas, tener en cuenta la expresión artística ha considerablemente renovado el enfoque de las migraciones. En particular, las producciones musicales han sido consideradas como una forma privilegiada de reunir imaginarios migratorios. ¿Es la música, y especialmente el rap, entonces solo la representación fiel de una palabra migrante? Al poner la imaginación migratoria en perspectiva con la experiencia de la movilidad durante carreras artísticas, utilizando los ejemplos de los grupos de rap senegaleses Wagëblë y Daara-J Family, el artículo muestra cómo los artistas pueden apelar a un imaginario migratorio particular, el de "soldado" preferablamente al de

"aventurero", para poner en escena su carrera artística, de acuerdo con las convenciones específicas del género musical al que desean pertenecer.

\section{INDEX}

\section{Geographical index: Sénégal}

Palabras claves: imaginarios migratorios, carreras artísticas, soldado, aventurero, rap, Senegal Keywords: migratory imaginaries, artistic careers, soldier, aventurer, rap, Senegal

Mots-clés: imaginaire migratoire, carrières artistiques, soldat, aventurier, rap

\section{AUTHOR}

\section{CÉCILE NAVARRO}

Post-doctoral fellow and affiliated researcher at the University of Lausanne, Haute École de Suisse Occidentale Valais, Institut Santé, Chemin de l'Agasse 5, 1950 Sion, Switzerland ; cecile.navarro@hevs.ch 